\title{
A Brief Discourse on the Comparison Between Class Group Counseling and Thematic Oral Chinese Teaching
}

\author{
Lu Ying-yi ${ }^{1}$
}

${ }^{1}$ FunnyQ Culture communication co., LTD

vivian@mengdouschool.com

\begin{abstract}
Although pedagogy and psychology are two disciplines with different research directions, yet they are very closely related, and both study on people and their development. Group psychological counseling is designed to help people who have common development problems and encounter similar psychological distress. It is an effective method of psychological counseling and an effective method of education and growth. Class group counseling is a group counseling for members who have similar conditions, backgrounds, or problems to carry out planned, prepared, and fixed-level activities to implement group counseling, usually members are students. In the teaching of Chinese as a foreign language in recent years, thematic teaching has received attention and is used in teaching, and thematic oral Chinese teaching is also developed around topic discussions. This paper mainly considers whether the form of class group counseling or subjective content can be applied to thematic oral Chinese teaching from the perspective of the two activities.
\end{abstract}

Keywords: structured, class group counseling, topic-based teaching, oral Chinese teaching

\section{INTRODUCTION}

As the country becomes more prosperous, the teaching of Chinese as a foreign language is also booming. The teaching models and teaching methods that have been used in the teaching of English as a second language are also being used as reference in the teaching of Chinese as a second language. Among them, the thematic teaching model is also used by some Chinese teachers and related papers in oral Chinese teaching have been published. Counseling is becoming more and more popular in China. As a technique of counseling, group counseling has a history of nearly 100 years in the West. Compared with mainland China, there are only more than ten years of practical experience. However, group counseling has been widely used in the society.

A class is essentially a learning group, and a homogeneous group basically consists of members with similar conditions, backgrounds or problems, such as college students who are similar in age, educational level, and living environment. When members conduct counseling on a common topic, it usually involves topicrelated vocabulary, expressions, and activities. The interaction and norms of group members can actually be indirectly used as rules of activities and class among members. Drawing on the characteristics of group counseling, it may be possible to transfer some forms or contents of group counseling to thematic oral Chinese teaching.

\section{CLASS GROUP PSYCHOLOGICAL COUNSELING}

First of all, we must know that group counseling is a type of group psychological inquiry. Group counseling is an economical and effective method designed to help people with common development problems or similar psychological distress. It can be widely used in educational institutions, corporate organizations, and social welfare institutions. It is not only an effective method of counseling and treatment, but also an effective method of education and growth. "Because it is very close to real life, like a life laboratory, the attitudes and behaviors learned in the group changed the emotions and understandings, which are easier to transfer to real life." (1)

Secondly, group counseling mainly emphasizes cognitive or knowledge-level functions, and the main goal is to provide information or transmit knowledge. 
Structured group counseling refers to activities that have been fully planned and prepared in advance and arranged for fixed procedures for the group to carry out. Leaders adopt corresponding guidance skills to promote interaction among members of the group.

Thirdly, the group counseling will have a group leader, that is, the person responsible for leading and guiding the direction of the group during the group activities. Among them, one of the leadership behaviors of cognitive leaders is cognitive education behavior -

- "Leaders with cognitive education behavior use traditional teaching methods such as explanations and instructions to guide members. The role of the leader is like a teacher....."

And class group counseling imparts knowledge through teaching activities mainly at the cognitive and knowledge level. "From the perspective of content, the counseling class brings together various theories and methods of human learning, life, health and psychology, and the content is selected based on the psychological age characteristics and needs of students..... From the perspective of learning activities, counseling class is based on experience as the carrier. The learning method must be conscious acceptance of the individual, without compulsory acceptance requirements ...... but in the form of activities, under the design and guidance of the teacher, let students experience and feel the content and significance in the activity....." (Xu Junmin) Liao Fengchi, a psychologist from Taiwan, also believes that the class counseling activity is student-centered, the content of the course is closely related to actual life, and the counseling course is a formal counseling rather than a class of game, and has to conduct teaching selfevaluation.

Therefore, class group counseling can be planned and prepared for members with similar backgrounds (such as college students, middle school students, etc.), with a fixed process and a member-centered approach led by a leader (psychological teacher or counselor). It is very close to reality so that the content can be transferred from the activity class to real life.

\section{THEMATIC ORAL CHINESE TEACHING}

Oral language teaching is one of the important skill courses in teaching Chinese as a foreign language. Its teaching goal is to improve the oral communication skills of foreign students. It is judged from several dimensions such as the accuracy of expression, fluency, correctness and appropriateness of words. Oral language teaching requires students to master certain language knowledge and cultural background knowledge related to the topic.

The learning situation constructed by thematic teaching is based on the students' knowledge level and actual life. It requires students to conduct independent exploration and learning during situated learning, and fully values the subjective initiative of students. At the same time, it requires teachers and students to be both the organizers and explorers of the learning situation, which is conducive to a harmonious teacher-student relationship; fourthly, thematic teaching also creates a certain problem situation for students, which is conducive to stimulating students' interest in learning, while allowing students to discuss and study in groups is beneficial for training students' team spirit and communication skills.

Thematic oral teaching is helpful in broadening students' vocabulary, enriching cultural knowledge, consolidating students' textbook knowledge and improving their ability to express in paragraphs, which is worthy of promotion and use. Nowadays, there are also many teachers who are using thematic mode for oral teaching. We can emphasize certain content as the focus and use some programmatic teaching activities as the framework for teaching.

(1) FAN Fu-min. HE Jin. Theory, Technology and Design of Group Counseling. First Edition, 2014 June

\section{THE TRANSFER OF CLASS GROUP COUNSELING ACTIVITIES TO THEMATIC ORAL TEACHING ACTIVITIES}

This content only represents the superficial ideas of the author of this paper. Counseling and Chinese teaching involve the study of human cognitive psychology. Here is a class group counseling activity as an example to study the relevance of class group counseling activities and thematic oral teaching.

The name of the activity is "Born a Talent", and the goal of the activity was to help members discover and recognize the advantages of self-consciousness, enhance their confidence, and learn to appreciate the advantages of others. The content of the activity is as follows - -

“Born a Talent” Activity Objectives and Operations

\begin{tabular}{|c|c|}
\hline $\begin{array}{l}\text { Purpose: Through this } \\
\text { activity, help members } \\
\text { understand their own } \\
\text { strengths, cherish their } \\
\text { potential, learn self- } \\
\text { appreciation, self- } \\
\text { affirmation, learn to } \\
\text { appreciate others, and } \\
\text { enhance self-confidence } \\
\text { and trust. Duration: } \\
\text { about } 20 \text { minutes }\end{array}$ & $\begin{array}{l}\text { 1. Born a Talent } \\
\text { Procedure: The } \\
\text { members sit in groups, } \\
\text { the counselor first } \\
\text { introduces the activity, } \\
\text { and each member is } \\
\text { given a "Born a Talent" } \\
\text { exercise sheet. Group } \\
\text { members are asked to } \\
\text { fill the sheet up and then } \\
\text { tell their answers to the } \\
\text { group. } \\
\text { Requirement: After each } \\
\text { participant has told the } \\
\text { answer of the same } \\
\text { item, proceed to the next } \\
\text { item. }\end{array}$ \\
\hline
\end{tabular}




\begin{tabular}{|c|c|}
\hline & $\begin{array}{l}\text { After all the members } \\
\text { have finished speaking, } \\
\text { start the group } \\
\text { discussion: Do you } \\
\text { agree that "everyone } \\
\text { has strengths"? What is } \\
\text { the reason? } \\
\text { When you introduce } \\
\text { your strengths to others, } \\
\text { do you feel that it is } \\
\text { different from your } \\
\text { previous understanding } \\
\text { of them? yom feel when } \\
\text { How do you } \\
\text { you discover that others } \\
\text { have so many } \\
\text { advantages? }\end{array}$ \\
\hline $\begin{array}{l}\text { Purpose: Learn to } \\
\text { discover the advantages } \\
\text { of others, learn to } \\
\text { appreciate others, and } \\
\text { promote long-term } \\
\text { mutual acknowledgment } \\
\text { and acceptance. } \\
\begin{array}{l}\text { Duration: about } 25 \\
\text { minutes }\end{array}\end{array}$ & $\begin{array}{l}\text { 2. Strengths } \\
\text { Bombardment } \\
\text { Operation: Members sit } \\
\text { in groups, each group is } \\
\text { given a newspaper to } \\
\text { fold a hat with, ask a } \\
\text { classmate to sit in the } \\
\text { center of the group and } \\
\text { put the hat on, and } \\
\text { accept 'bombardments' } \\
\text { from other members of } \\
\text { the group: each member } \\
\text { takes turns to speak out } \\
\text { his (her) strengths and } \\
\text { admiration (such as } \\
\text { personality, } \\
\text { appearance, treatment, } \\
\text { etc.), the bombarded } \\
\text { person should sincerely } \\
\text { say "thank you" to those } \\
\text { who praised him/her. } \\
\text { All members of the } \\
\text { group received the } \\
\text { "strengths } \\
\text { bombardment" in turn. } \\
\text { Requirements: You must } \\
\text { praise the strengths of } \\
\text { others, be specific when } \\
\text { you praise, and have a } \\
\text { sincere attitude. You } \\
\text { must work hard to } \\
\text { discover the strengths of } \\
\text { others. You must not } \\
\text { praise others baselessly } \\
\text { as this will hurt others. } \\
\text { After the session has } \\
\text { ended, the members } \\
\text { discuss in the group: } \\
\text { which advantages had } \\
\text { they previously noticed } \\
\text { when they were praised, } \\
\text { and which ones they did } \\
\text { not know before. How do } \\
\text { you feel when you are } \\
\text { praised? How do you } \\
\text { feel when you praise } \\
\text { others? }\end{array}$ \\
\hline
\end{tabular}

Fig. 1 Activity "Born a Talent" (1)
The activity materials given to the members are as follows - -

Activity material issues:

1. What I admire most about my appearance is

2. What I feel most fulfilling in my studies is

3. What my classmates like most about me is

4. What I am most satisfied with my parents is

5. My contribution to the class is

6 . The teacher's remark that makes me most happy is

7. My most satisfied exam is

8. My favorite course is

9. My attitude towards learning that I appreciate the most is

\section{"Born a Talent" Event Materials (2)}

If this activity is presented as a thematic oral class of Chinese as a foreign language, the whole activity can use "expressing advantages" as the theme, involving several aspects: expressing one's own strengths, expressing the strengths of others, the feelings of praising oneself, the feelings when others praise of you and the feelings when you praise of others.

The teacher can first divide the students in the class into several groups, with the number of each group as even as possible, and everyone has a copy of the activity materials in their hands. In the first part of the activity - for each advantage listed in the materials, everyone in the group must say it once before proceeding to the next item. This will not only help members understand the meaning of the options, but also make it easy to record the corresponding advantages of other members and training the students' writing expression skills. The new vocabulary or out-of-syllabus vocabulary, language points and sentence structure involved in this part will be taught by the teacher in advance.

Secondly, in the second part - - the group discussion "Do you agree that everyone has strengths/advantages? How do you feel when you introduce your strengths to others..." and other questions involve paragraphs of expression, which can train the members' ability to organize language and articulate sentence groups. As an "observer", the teacher listens to the members' expressions in different groups and encourages everyone to speak more and use the words as accurately as possible.

In the third part, one member of each group wears a "top hat", and other members praise him/her, saying his/her character strengths or what they appreciate of him/her. The expressions of the members can be phrases or sentences to train students on related expressions of 
human strengths and advantages. Make sure that every member has to experience being praised with a "top hat". The teacher observes and maintains order in the vicinity.

In the fourth part, let the group members discuss a few questions at the end:

1. Which of the mentioned advantages do you know and which ones you don't?

2. How does it feel to be praised?

3. How does it feel to praise others?

(1)2Excerpts from Fan Fumin, He Jin, "Group Counseling", First edition, July 2010

Finally, the teacher, as a responder, can summarize the words, phrases, and sentence patterns used in the entire activity to assign homework.

\section{CONCLUSION}

The activity process is presented in the language class on the basis of understanding the psychological goals, which not only helps students master and express the content of the subject of "praise", but also benefits the physical and mental health of the students, yielding winwin effects. However, there are many uncertainties in applying the activities of class group counseling to thematic oral teaching. For example, the members of the group counseling are all Chinese natives with Chinese language skills or authentic and fluent language expression, while the students of the Chinese as foreign language class are foreign students from different cultural backgrounds. Secondly, the Chinese proficiency of the students in the class will also be highly uneven, and the implementation of activities may be quite difficult. It is necessary for teachers to simplify the process of tutoring activities or the expression of discussion content, or carry out applicable psychological activities in groups of foreign students who meet the corresponding Chinese proficiency. Thirdly, in order to facilitate the operation of teachers, the class size should not be too large so that the teacher can randomly listen to the expressions of the members in different groups and track the students' oral errors during the activities. The last thing to consider is that the group counseling activities are not necessarily suitable for thematic oral teaching, and the teacher needs to be screened and redesigned when preparing lessons. This procedure will consume a lot of time and energy for the teacher. It also requires the teacher to have experience in teaching Chinese as a foreign language and group counseling at the same time. The requirements for the teacher will be relatively high. At the same time, whether the designed activity can achieve the expected psychological goal is also unknown.

\section{REFERENCES}

[1] BAI Jian-hua. Selected Papers of the 10th International Chinese Language Teaching Seminar • The Development and Application of Thematic Teaching in the 21st Century.: Wanjuan Publishing Company, 2012: 1-2

[2] FAN Fu-min. The Development of Group Counseling in China: Review and Prospect [J]. Journal of Tsinghua University (Philosophy and Social Sciences), 2005, 020(006): 62-69.

[3] FAN Fu-min. HE Jin. Theory, Technology and Design of Group Counseling. First Edition, 2014 June

[4] FAN Fu-min. HE Jin. Group Counseling. First Edition, 2014 July

[5] LIU Man-man. The Application of Thematic Teaching Model in Intermediate Oral Teaching of Chinese as a Foreign Language [D].

[6] YANG Kai. The Application of Thematic Teaching Model in Oral Chinese Teaching [D]. 